\title{
Human Problem Solving in 2006
}

\author{
Zygmunt Pizlo
}

\begin{abstract}
This paper presents a bibliography of a little more than 100 references related to human problem solving, arranged by subject matter. The references were taken from Psyclnfo and Compendex databases. Only journal papers, books and dissertations are included.The topics include human development, education, neuroscience, research in applied settings, as well as animal studies. A few references from artificial intelligence are also given.
\end{abstract}

\section{Introduction}

Note that this bibliography is not very large, indicating the relatively small number of researchers working on human problem solving.This agrees with the JPS Editorial Board's informal evaluation of the state of our field when we decided to start a new journal. Next, note that quite a few dissertations on human problem solving were defended last year. Compared to the number of journal papers, the number of dissertations is quite large. Does this mean that it is difficult to publish a paper in the area of problem solving? If this conclusion is accurate, then the Journal of Problem Solving can remedy the situation.

Below there are names of journals that published papers on human problem solving, last year. There were 95 papers published in 67 journals. The mode was one publication per journal (49 papers in 49 journals). There were 14 journals with two publications each, and four journals that published three, four, five and six papers, respectively. The maximal number of publications (six) was published in this journal: the Journal of Problem Solving. These facts clearly show that there has been no journal devoted to human problem solving. This is an undesirable situation for more than one reason. First, students of problem solving have to keep track of large number of journals. Second, editors handling papers on human problem solving do not have a large pool of reviewers who are easily accessible. This fact may lead to subsequent problems such as duration and, potentially, the quality of the review process.

Purdue University, Department of Psychological Sciences, 703 Third Street, West Lafayette, IN 47907-2081

Email:pizlo@pysclops.psych.purdue.edu

The Journal of Problem Solving • volume 1, no. 2 (Spring 2007) 


\section{List of Journals}

(The number of publications for each journal is shown in parentheses.)

Al Magazine

Animal Behaviour

Animal Cognition

Applied Animal Behaviour Science

Applied Cognitive Psychology

Artificial Intelligence (2)

Artificial Intelligence in Medicine

Assessment for Effective Intervention

Behaviour \& Information Technology

Behavioral and Cognitive Neuroscience Reviews

Behavioral Neuroscience

Biological Psychiatry

Brain Injury (2)

British Journal of Psychology

Child Development (2)

Clinical Child Psychology and Psychiatry

Clinical Neuropsychologist

Cognitive Psychology

Cognitive Science (2)

Communications of the ACM

Computers in Human Behavior (4)

Contemporary Educational Psychology

Creativity Research Journal (2)

Developmental Science

Educational Psychology in Practice

Ethology

European Journal of Cognitive Psychology

European Journal of Psychology of Education

European Journal of Special Needs Education

Experimental Psychology

IEEE Computational Intelligence Magazine

IEEE Intelligent Systems

Imagination, Cognition and Personality

Infant and Child Development

International Journal of Human-Computer Interaction

Journal for Research in Mathematics Education (5)

Journal of Cognitive Neuroscience (2) 


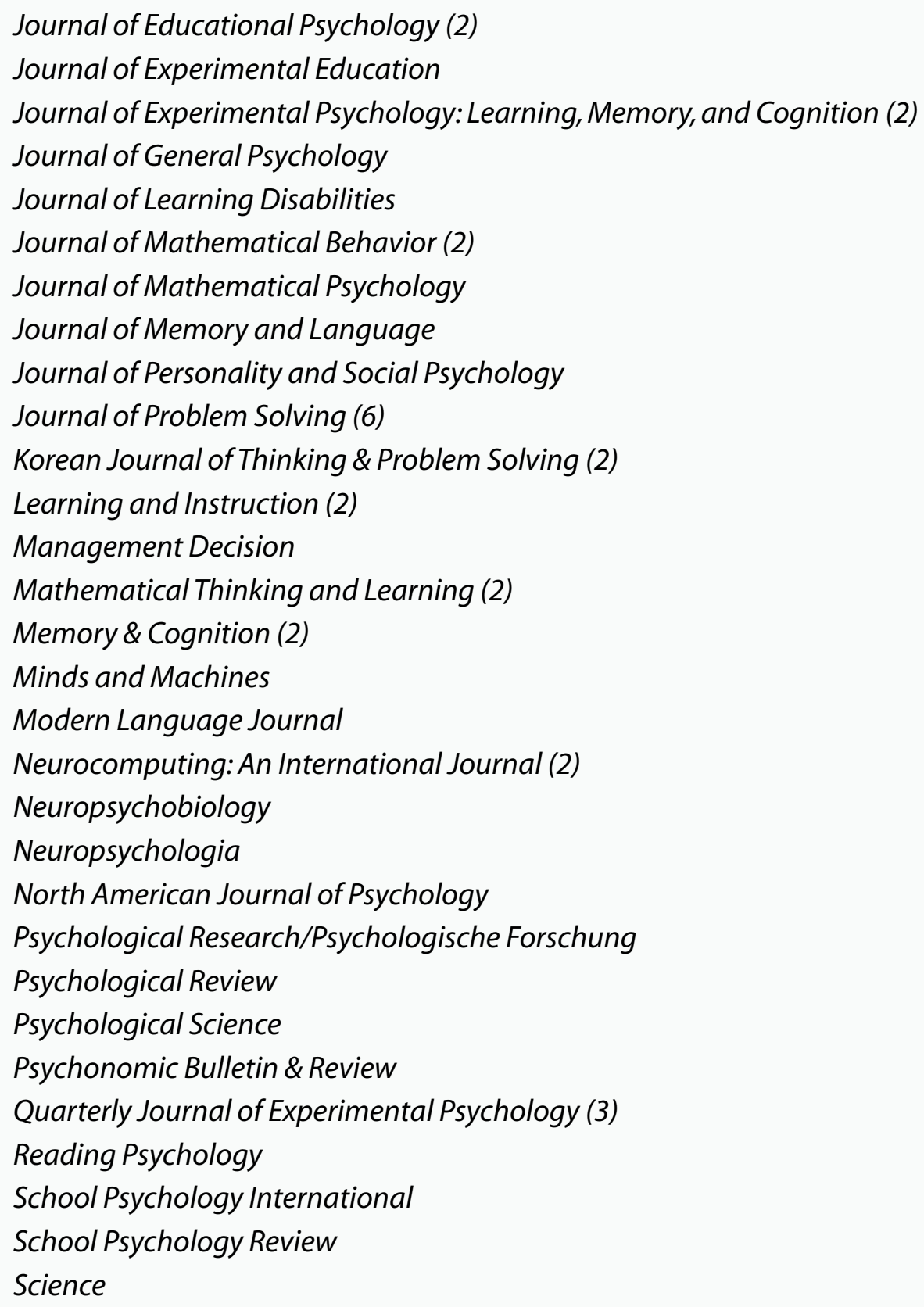

\section{Bibliography}

\section{General}

Ash, I.K. \& Wiley, J. (2006) The nature of restructuring in insight: An individual-differences approach. Psychonomic Bulletin \& Review, 13(1), 66-73.

Bearden, J.N. (2006) A new secretary problem with rank-based selection and cardinal payoffs. Journal of Mathematical Psychology, 50(1), 58-59. 
Brophy, D.R. (2006) A comparison of individual and group efforts to creatively solve contrasting types of problems. Creativity Research Journal, 18(3), 293-315.

Burns, N.R., Lee, M.D.\& Vickers, D. (2006) Are individual differences in performance on perceptual and cognitive optimization problems determined by general intelligence? Journal of Problem Solving, 1, 5-19.

Catrambone, R., Craig, D.L. \& Nersessian, N.J. (2006) The role of perceptually represented structure in analogical problem solving. Memory \& Cognition, 34(5), 1126-1132.

Chronicle, E.P., MacGregor, J.N. \& Ormerod, T.C. (2006) Optimizing and "pessimizing": human performance with instructional variants of the traveling salesperson problem. Journal of Problem Solving, 1,74-82.

Chronicle, E.P., MacGregor, J.N., Ormerod, T.C. \& Burr, A. (2006) It looks easy! Heuristics for combinatorial optimization problems. Quarterly Journal of Experimental Psychology, 59(4), 783-800.

Chrysikou,E.G. (2006) When shoes become hammers:Goal-derived categorization training enhances problem-solving performance.Journal of Experimental Psychology:Learning, Memory, and Cognition, 32(4), 935-942.

Connell, L. \& Keane, M.T. (2006) A model of plausibility. Cognitive Science, 30(1), 95-120.

Deschuyteneer, M.,Vandierendonck, A.\& Muyllaert,I. (2006) Does solution of mental arithmetic problems such as $2+6$ and $3 \times 8$ rely on the process of "memory updating"? Experimental Psychology, 53(3), 198-208.

Dry, M., Lee, M.D.,Vickers, D.\& Hughes, P. (2006) Human performance on visually presented traveling salesperson problems with varying numbers of nodes. Journal of Problem Solving, 1, 20-32.

Fu,W.-T.\& Gray,W.D.(2006) Suboptimal tradeoffs in information seeking. Cognitive Psychology, 52(3), 195-242.

Gray, W.D., Sims, C.R., Fu, W.-T. \& Schoelles, M.J. (2006) The soft constraints hypothesis: A rational analysis approach to resource allocation for interactive behavior.Psychological Review, 113(3), 461-482.

Hecht, S. A. (2006) Group differences in adult simple arithmetic: Good retrievers, not-sogood retrievers, and perfectionists. Memory \& Cognition, 34(1), 207-216.

Helfenstein, S. \& Saariluoma, P. (2006) Mental contents in transfer. Psychological Research/ Psychologische Forschung, 70(4), 293-303.

Lee, M.D. (2006) A hierarchical Bayesian model of human decision-making on an optimal stopping problem. Cognitive Science, 30(3), 555-580.

Lozano,S.C.\&Tversky, B.(2006) Communicative gestures facilitate problem solving for both communicators and recipients. Journal of Memory and Language, 55(1), 47-63.

MacGregor, J.N., Chronicle, E.P. \& Ormerod, T.C. (2006) A comparison of heuristic and human performance on open versions of the traveling salesperson problem. Journal of Problem Solving, 1,33-43.

- volume 1, no. 2 (Spring 2007) 
Na,S.U.(2006) The effect of expertise on creative problem solving. Korean Journal of Thinking \& Problem Solving, 16(1), 65-74.

Novick, L.R.(2006) Understanding spatial diagram structure:An analysis of hierarchies, matrices, and networks. Quarterly Journal of Experimental Psychology, 59(10), 1826-1856.

Pizlo, Z., Stefanov, E., Saalweachter, J., Li, Z., Haxhimusa, Y. \& Kropatsch, W.G. (2006) Traveling salesman problem: A foveating pyramid model. Journal of Problem Solving, 1 , 83-101.

Rieskamp, J. (2006) Perspectives of probabilistic inferences: Reinforcement learning and an adaptive network compared.Journal of Experimental Psychology:Learning, Memory, and Cognition, 32(6), 1355-1370.

Sigler, E.A.\& Tallent-Runnels, M.K. (2006) Examining the validity of scores from an instrument designed to measure metacognition of problem solving. Journal of General Psychology, 133(3), 257-276.

Thevenot, C. \& Oakhill, J. (2006) Representations and strategies for solving dynamic and static arithmetic word problems: The role of working memory capacities. European Journal of Cognitive Psychology, 18(5), 756-775.

Unterrainer, J.M., Kaller, C.P., Halsband, U. \& Rahm, B. (2006) Planning abilities and chess: A comparison of chess and non-chess players on the Tower of London task. British Journal of Psychology, 97(3), 299-311.

Wieth, M. \& Burns, B.D. (2006) Incentives improve performance on both incremental and insight problem solving. Quarterly Journal of Experimental Psychology, 59(8), 1378-1394.

\section{Development}

Amsterlaw,J.(2006) Children's beliefs about everyday reasoning.Child Development, 77(2), 443-464.

Burton, C.L., Strauss, E., Hultsch, D.F.\& Hunter, M.A. (2006) Cognitive functioning and everyday problem solving in older adults. Clinical Neuropsychologist, 20(3), 432-452.

Cox, R.F.A. \& Smitsman, A.W. (2006) Action planning in young children's tool use. Developmental Science, 9(6), 628-641.

Goubet, N., Rochat, P., Maire-Leblond, C. \& Poss, S. (2006) Learning from others in 9-18month-old infants. Infant and Child Development, 15(2), 161-177.

Street, E. (2006) Test of time: A review of change: Principles of problem formation and problem resolution. Clinical Child Psychology and Psychiatry, 11(2), 301-306.

van Rooij, I., Schactman, A., Kadlec, H. \& Stege, U. (2006) Perceptual or analytical processing? evidence from children's and adults' performance on the Euclidean traveling salesperson problem. Journal of Problem Solving, 1,44-73.

Warneken, F., Chen, F. \& Tomasello, M. (2006) Cooperative activities in young children and chimpanzees. Child Development, 77(3), 640-663. 


\section{Education}

Annevirta,T.\&Vauras, M.(2006) Developmental changes of metacognitive skill in elementary school children. Journal of Experimental Education, 74(3), 197-225.

Arts, J.A.R., Gijselaers, W.H. \& Segers, M.S.R. (2006) Enhancing problem-solving expertise by means of an authentic, collaborative, computer supported and problem-based course. European Journal of Psychology of Education, 21(1), 71-90.

Barrett, J.E., Clements, D.H., Klanderman, D., Pennisi, S-J. \& Polaki, M.V. (2006) Students' coordination of geometric reasoning and measuring strategies on a fixed perimeter task: Developing mathematical understanding of linear measurement. Journal for Research in Mathematics Education, 37(3), 187-221.

Cook, J.L. (2006) College students and algebra story problems: Strategies for identifying relevant information. Reading Psychology, 27(2-3), 95-125.

Desoete, A.\& Roeyers, H. (2006) Metacognitive macroevaluations in mathematical problem solving. Learning and Instruction, 16(1), 12-25.

Empson, S.B.\&Turner, E. (2006) The emergence of multiplicative thinking in children's solutions to paper folding tasks. Journal of Mathematical Behavior, 25(1), 46-56.

Fuchs, L.S., Fuchs, D., Compton, D.L., Powell, S.R., Seethaler, P.M., Capizzi, A.M., Schatschneider, C. \& Fletcher, J.M. (2006) The cognitive correlates of third-grade skill in arithmetic, algorithmic computation, and arithmetic word problems. Journal of Educational Psychology, 98(1), 29-43.

Gainsburg, J. (2006) The mathematical modeling of structural engineers. Mathematical Thinking and Learning, 8(1), 3-36.

Garcia, A.I., Jimenez, J.E. \& Hess, S. (2006) Solving arithmetic word problems: An analysis of classification as a function of difficulty in children with and without arithmetic LD. Journal of Learning Disabilities, 39(3), 270-281.

Greenwood, C.R., Walker, D., Carta, J.J.\& Higgins, S.K. (2006) Developing a general outcome measure of growth in the cognitive abilities of children 1 to 4 years old: The early problem-solving indicator. School Psychology Review, 35(4), 535-551.

Harskamp, E.G. \& Suhre, C.J.M. (2006) Improving mathematical problem solving: A computerized approach. Computers in Human Behavior, 22, 801-815.

Kalyuga, S. (2006) Rapid cognitive assessment of learners' knowledge structures. Learning and Instruction, 16(1), 1-11.

Kelly, B. (2006) Exploring the usefulness of the Monsen problem-solving framework for applied practitioners. Educational Psychology in Practice, 22(1), 1-17.

Knuth, E.J.,Stephens, A.C.,McNeil, N.M.\& Alibali, M.W.(2006) Does understanding the equal sign matter? Evidence from solving equations. Journal for Research in Mathematics Education, 37(4), 297-312.

Reikeras, E.K.L.(2006) Performance in solving arithmetic problems:A comparison of children with different levels of achievement in mathematics and reading. European Journal of Special Needs Education, 21(3), 233-250.

- volume 1, no. 2 (Spring 2007) 
Sanchez,J.\&Saenz, M. (2006) 3D sound interactive environments for blind children problem solving skills. Behaviour \& Information Technology, 25(4), 367-378.

Senk, S.L.\&Thompson, D.R.(2006) Strategies used by second-year algebra students to solve problems. Journal for Research in Mathematics Education, 37(2), 116-128.

Shamir, A., Tzuriel, D. \& Rozen, M. (2006) Peer mediation:The effects of program intervention, maths level, and verbal ability on mediation style and improvement in maths problem solving. School Psychology International, 27(2), 209-231.

Smith, J.C. (2006) A sense-making approach to proof: Strategies of students in traditional and problem-based number theory courses. Journal of Mathematical Behavior, 25(1), 73-90.

Star, J.R.\& Seifert, C. (2006) The development of flexibility in equation solving. Contemporary Educational Psychology, 31(3), 280-300.

Stein, M. \& Burchartz, B. (2006) The invisible wall project: reasoning and problem solving processes of primary and lower secondary students. Mathematical Thinking and Learning, 8(1), 65-90.

Swanson, H.L. (2006) Cross-sectional and incremental changes in working memory and mathematical problem solving. Journal of Educational Psychology, 98(2), 265-281.

Wood, T., Williams, G. \& McNeal, B. (2006) Children's mathematical thinking in different classroom cultures. Journal for Research in Mathematics Education, 37(3), 222-255.

Yeo, K.K.J. (2006) Mathematical problem-solving heuristics used by secondary 2 students. Korean Journal of Thinking \& Problem Solving, 16(2), 53-69.

Yerushalmy, M. (2006) Slower algebra students meet faster tools: Solving algebra word problems with graphing software. Journal for Research in Mathematics Education, 37(5), 356-387.

\section{Applied}

Asato, M.R., Sweeney, J.A. \& Luna, B. (2006) Cognitive processes in the development of TOL performance. Neuropsychologia, 44(12), 2259-2269.

Best, J. (2006) Conditional reasoning in the context of strategy development in the logical deduction game "Mastermind." North American Journal of Psychology, 8(2), 345-372.

Crowley,R.S.\& Medvedeva,O.(2006) An intelligent tutoring system for visual classification problem solving. Artificial Intelligence in Medicine, 36(1), 85-117.

Harskamp, E.G. \& Suhre, C.J.M. (2006) Improving mathematical problem solving: A computerized approach. Computers in Human Behavior, 22(5), 801-815.

Hollenbeck, K., Twyman,T.\&Tindal, G. (2006) Determining the exchangeability of concept map and problem-solving essay scores. Assessment for Effective Intervention, 31(2), 51-68.

Hummel, H.G.K., Paas, F.\& Koper, E.J.R.(2006) Timing of cueing in complex problem-solving tasks: Learner versus system control. Computers in Human Behavior, 22(2), 191-205. 
Kalyuga, S. (2006) Assessment of learners' organised knowledge structures in adaptive learning environments. Applied Cognitive Psychology, 20(3), 333-342.

de Larios, J.R., Manchon, R.M. \& Murphy, L. (2006) Generating text in native and foreign language writing: A temporal analysis of problem-solving formulation processes. Modern Language Journal, 90(1), 100-114.

Laughlin, P.R., Hatch, E.C., Silver, J.S. \& Boh, L. (2006) Groups perform better than the best individuals on letters-to-numbers problems: Effects of group size.Journal of Personality and Social Psychology, 90(4), 644-651.

Man, D.W-K.,Soong,W.Y.L.,Tam, S-F.\& Hui-Chan, C.W.Y.(2006) Development and evaluation of a pictorial-based analogical problem-solving programme for people with traumatic brain injury. Brain Injury, 20(9), 981-990.

Nakatsu, R.T.\& Benbasat, I. (2006) Designing intelligent systems to handle system failures: Enhancing explanatory power with less restrictive user interfaces and deep explanations. International Journal of Human-Computer Interaction, 21(1), 55-72.

Osburn, H.K. \& Mumford, M.D. (2006) Creativity and planning: Training interventions to develop creative problem-solving skills. Creativity Research Journal, 18(2), 173-190.

Otto,J.H.\& Lantermann, E.-D. (2006) Individual differences in emotional clarity and complex problem solving. Imagination, Cognition and Personality, 25(1), 3-24.

Scheiter, K., Gerjets, P. \& Catrambone, R. (2006) Making the abstract concrete:Visualizing mathematical solution procedures. Computers in Human Behavior, 22(1), 9-25.

Walker, E.D.\& Cox, J.F. (2006) Addressing ill-structured problems using Goldratt's thinking processes: A white collar example. Management Decision, 44(1), 137-154.

\section{Neuroscience}

Kirsch, P., Lis, S., Esslinger, C., Gruppe, H., Danos, P., Broll, J., Wiltink, J. \& Gallhofer, B. (2006) Brain activation during mental maze solving. Neuropsychobiology, 54(1),51-58.

Kounios, J., Frymiare, J.L., Bowden, E.M., Fleck, J.I., Subramaniam, K., Parrish, T.B. \& JungBeeman, M. (2006) The prepared mind: Neural activity prior to problem presentation predicts subsequent solution by sudden insight. Psychological Science, 17(10), 882-890.

Lang, S., Kanngieser, N., Jaskowski, P., Haider, H., Rose, M. \& Verleger, R. (2006) Precursors of insight in event-related brain potentials. Journal of Cognitive Neuroscience, 18(12), 2152-2166.

Voelbel, G.T., Bates, M.E., Buckman, J.F., Pandina, G. \& Hendren, R.L. (2006) Caudate nucleus volume and cognitive performance: Are they related in childhood psychopathology? Biological Psychiatry, 60(9), 942-950.

Wichert, A. (2006) Cell assemblies for diagnostic problem-solving. Neurocomputing: An International Journal, 69(7-9), 810-824.

- volume 1, no. 2 (Spring 2007) 


\section{Animal}

Andersen, I.L., Naevdal, E., Boe, K.E.\& Bakken,M.(2006) The significance of theories in behavioural ecology for solving problems in applied ethology. Possibilities and limitations. Applied Animal Behaviour Science, 97(1), 85-104.

Bond, A.H. (2006) Brain mechanisms for interleaving routine and creative action. Neurocomputing: An International Journal, 69(10-12), 1348-1353.

Cazalis, F., Feydy, A., Valabregue, R., Pelegrini-Issac, M., Pierot, L. \& Azouvi, P. (2006) fMRI study of problem-solving after severe traumatic brain injury. Brain Injury, 20(10), 1019-1028.

Cabrera, S.M., Chavez, C.M., Corley, S.R., Kitto, M.R.\& Butt, A.E. (2006) Selective lesions of the nucleus basalis magnocellularis impair cognitive flexibility. Behavioral Neuroscience, 120(2), 298-306.

Fangmeier,T., Knauff,M., Ruff,C.C.\&Sloutsky,V.(2006) fMRI Evidence for a three-stage model of deductive reasoning. Journal of Cognitive Neuroscience, 18(3), 320-334.

Melis, A.P., Hare, B. \& Tomasello, M. (2006) Chimpanzees recruit the best collaborators. Science, $311, \boldsymbol{n} .5765,1297-1300$.

Menzel, R. \& Giurfa, M. (2006) Dimensions of cognition in an insect, the honeybee. Behavioral and Cognitive Neuroscience Reviews, 5(1), 24-40.

Mulcahy, N.J.\& Call,J.(2006) How great apes perform on a modified trap-tube task.Animal Cognition, 9(3), 193-199.

Seibt,U.\&Wickler,W.(2006) Individuality in problem solving:String pulling in two Carduelis species (Aves: Passeriformes). Ethology, 112(5), 493-502.

Werdenich, D. \& Huber, L. (2006) A case of quick problem solving in birds:String pulling in keas, Nestor notabilis. Animal Behaviour, 71(4), 855-863.

\section{Artificial Intelligence}

Coradeschi, S., Ishiguro, H., Asada, M., Shapiro, S.C., Thielscher, M., Breazeal, C., Mataric, M.J. \& Ishida, H. (2006) Human-inspired robots. IEEE Intelligent Systems, 21, 74-85.

Forbus, K.D. \& Hinrichs, T.R. (2006) Companion cognitive systems: A step toward humanlevel Al. Al Magazine, 27, 83-95.

Pentland, A. (2006) Collective intelligence. IEEE Computational Intelligence Magazine, 1, 9-12.

Schank, R. (2006) Once upon a time in Al. Artificial Intelligence, 170, 1254-1255.

Schmidt, C.T.A.\& Kraemer, F.(2006) Robots, Dennett and the autonomous: A terminological investigation. Minds and Machines, 16, 73-80.

Spector, L. (2006) Evolution of artificial intelligence. Artificial Intelligence, 170,1251-1253.

Wegner, P. \& Goldin, D. (2006) Principles of problem solving. Communications of the ACM, 49, 27-29. 


\section{Dissertations}

Best, B.J. Modeling human performance on the traveling salesman problem: Empirical studies and computational simulations. Dissertation Abstracts International: Section B:The Sciences and Engineering.Vol.66(11-B), 2006, p. 6302.

Bodvarsson, M.C. Prompting students to justify their response while problem-solving: A nested, mixed-methods study.Dissertation Abstracts International: Section A:Humanities and Social Sciences. Vol. 66(12-A), 2006, p. 4295.

Burgess, G.C.Relationships among fluid intelligence, working memory, executive attention, and academic success: Understanding their common neural mechanisms. Dissertation Abstracts International: Section B: The Sciences and Engineering. Vol. 66(10-B), 2006, p. 5701.

Chen, $\mathrm{S}$. The relationship between mathematical beliefs and performance: A study of students and their teachers in Beijing and New York (China). Dissertation Abstracts International: Section A:Humanities and Social Sciences.Vol. 66(9-A), 2006, p. 3208.

Chrysikou, E.G. When a shoe becomes a hammer: Problem solving as goal-derived, ad hoc categorization. Dissertation Abstracts International: Section B: The Sciences and Engineering.Vol.67(1-B), 2006, p. 569.

Connell, J.E.J. Constructing a math applications, curriculum-based assessment: An analysis of the relationship between applications problems, computation problems and criterion-referenced assessments. Dissertation Abstracts International: Section B:The Sciences and Engineering.Vol. 66(7-B), 2006, p. 3933.

Desai-Patel, S.P. An evaluation of the interactive problem solving method. Dissertation Abstracts International: Section B:The Sciences and Engineering.Vol.66(12-B), 2006, p. 6959.

Elias, J.S. The engineering design mind: A cognitive model and a case study. Dissertation Abstracts International: Section B:The Sciences and Engineering.Vol.66(11-B), 2006, p. 6304.

Fincham, J.M. Cognitive modeling and fMRI:An integrated approach toward understanding mechanisms of complex skill performance. Dissertation Abstracts International: Section B:The Sciences and Engineering.Vol.66(9-B), 2006, p. 5114.

Fournier, H.The nature of task representation by novice multimedia authors. Dissertation Abstracts International: Section A: Humanities and Social Sciences.Vol.67(2-A), 2006, p. 459.

Hausmann, R.G.M.Elaborative and critical dialog:Two potentially effective problem-solving and learning interactions.Dissertation Abstracts International:Section B:The Sciences and Engineering.Vol. 66(9-B), 2006, p. 5115.

Hewlett, A.K.Constructive thinking from theory to practice: An exploratory study.Dissertation Abstracts International: Section A: Humanities and Social Sciences. Vol. 66(10-A), 2006, p. 3551.

Horvath, M.J. Effect of practice method on problem-solving skill acquisition and process

- volume 1, no. 2 (Spring 2007) 
acceptability. Dissertation Abstracts International: Section A: Humanities and Social Sciences. Vol.67(4-A), 2006, p. 1222.

Kaczmarczyk, E.C.The acquisition of intellectual expertise: A computational and empirical theory. Dissertation Abstracts International: Section B:The Sciences and Engineering. Vol.66(12-B), 2006, p. 6726.

Lambert, M.H. Greater-than, equal-to, or less-than the sum of the parts: A study of collective information processing and information distribution in real-time cross-functional design.Dissertation Abstracts International: Section A:Humanities and Social Sciences. Vol.66(8-A), 2006, p. 2999.

Leelawong, K. Using the learning-by-teaching paradigm to design intelligent learning environments. Dissertation Abstracts International: Section B:The Sciences and Engineering.Vol. 66(9-B), 2006, p. 4907.

Pappas S., \& Sarantoula S. Fostering kindergarteners' metacognition.Dissertation Abstracts International: Section B:The Sciences and Engineering. Vol.66(9-B), 2006, pp. 5126.

Ramani, G.B.. Cooperative play and problem solving in preschool children. Dissertation Abstracts International: Section B: The Sciences and Engineering. Vol. 67(1-B), 2006, p. 579.

Reisslein, J. Learner achievement and attitudes under varying paces of transitioning to independent problem solving. Dissertation Abstracts International: Section A:Humanities and Social Sciences. Vol.66(11-A), 2006, p. 3993.

Reynolds, J.R. On the roles of duration and computational complexity in the recruitment of fronto-polar prefrontal cortex. Dissertation Abstracts International: Section B: The Sciences and Engineering. Vol.66(10-B), 2006, p. 5704.

Sullivan, F.R.The ideal science student and problem solving.Dissertation Abstracts International: Section A:Humanities and Social Sciences. Vol.66(9-A), 2006, p. 3214.

Virgolim, A.M.R. Creativity and intelligence: A study of Brazilian gifted and talented students.Dissertation Abstracts International: Section A:Humanities and Social Sciences. Vol.66(10-A), 2006, p. 3570.

Wieth, M.The influence of motivation on cognitive mechanisms involved in problem solving.Dissertation Abstracts International: Section B:The Sciences and Engineering. Vol. 66(9-B), 2006, p. 5118.

\section{Books}

Friedenberg, J. \& Silverman, G. (2006) Cognitive science: An introduction to the study of the mind. Thousand Oaks, CA: Sage Publications Ltd.

Kaufman, J.C. \& Baer, J. [Eds.] (2006) Creativity and reason in cognitive development. New York: Cambridge University Press.

Kuhn, D., Siegler, R.S., Damon, W. \& Lerner, R.M. [Eds.] (2006) Handbook of child psychology: Vol.2, Cognition, perception, and language. Hoboken, NJ: John Wiley \& Sons Inc. 
Mittel, A.V. [Ed.] (2006) Focus on educational psychology. Hauppauge, NY: Nova Science Publishers.

Stokes, P.D. (2006) Creativity from constraints: The psychology of breakthrough. New York: Springer Publishing Co.

Weisberg, R.W.(2006) Creativity:Understanding innovation in problem solving, science, invention, and the arts. Hoboken, NJ: John Wiley \& Sons, Inc.

Wasserman, E.A. \& Zentall, T.R. [Eds.] Comparative cognition: Experimental explorations of animal intelligence. New York: Oxford University Press.

Zazkis, R.\& Campbell, S.R. [Eds.]. Number theory in mathematics education:Perspectives and prospects. Mahwah, NJ: Lawrence Erlbaum Associates Publishers.

- volume 1, no. 2 (Spring 2007) 